\title{
ASPECTOS DO LIBERALISMO MODERADO NA PROVÍNCIA DO CEARÁ DOS ANOS 1830
}

\author{
Gustavo Magno Barbosa Alencar*
}

\begin{abstract}
RESUMO: Neste artigo, analisaremos as concepções do pensamento político liberal moderado que embasou os sujeitos que atuaram no processo de constituição deste partido no Ceará. Tal agrupamento se formou a partir de intensas articulações entre os anos de 1830 e 1837 (quando o Regresso conservador assume a administração imperial). Através de jornais, ofícios, proclamações e outras fontes documentais é que esta empreitada será viabilizada, entendendo que por meio da compreensão dos usos do vocabulário político é possível aprofundar os significados da cultura política liberal posta em prática.
\end{abstract}

PALAVRAS-CHAVE: liberalismo moderado; Vocabulário político; Província do Ceará.

\section{Aspects of moderate liberalism in Ceará Province during the 1830's}

\begin{abstract}
In this article, we will analyze the views of the moderate liberal political thought that based subjects who acted in the creation process of this party in Ceará. It was formed from intense joints between 1830 and 1837 (when the conservative Regress occupied the imperial administration). Through newspapers, official documents, proclamations and other sources, this effort will be made possible, understanding that through the analysis of the political vocabulary uses is possible to deepen the meanings of the liberal political culture practices.
\end{abstract}

KEYWORDS: Moderate liberalism; Political vocabulary; Ceará province.

\section{Aspectos do liberalismo moderado en la Provincia de Ceará en la década de 1830}

RESUMEN: En este artículo, analizamos las concepciones del pensamiento político liberal moderado de los sujetos que actuaron en el proceso de formación de este partido en Ceará. Esta agrupación se constituyó a través de intensas articulaciones entre los años 1830 y 1837 (cuando el Regresso conservador asumió la administración imperial). Utilizamos los periódicos, cartas, proclamas y otras fuentes documentales para realizar este análisis, teniendo en cuenta que mediante la comprensión de los usos del vocabulario político es posible profundizar en los sentidos de la cultura política liberal. PALABRAS CLAVE: Liberalismo moderado; Vocabulario político; Provincia de Ceará.

\footnotetext{
* Mestre em História Social pela Universidade Federal do Ceará e membro do grupo Sociedade e Cultura no Brasil Oitocentista - SEBO (http://dgp.cnpq.br/dgp/espelhogrupo/0590473751214961). Email: gustavombalencar@gmail.com
} 
No trecho abaixo, Lúcia Bastos Pereira das Neves enfoca o desenvolvimento da cultura política da Independência e a introdução de novos termos no vocabulário político brasileiro, um reflexo das questões postas à sociedade naquele momento.

O vocabulário político foi ampliado, com a redefinição de antigas palavras e a introdução de novos termos, cujos significados, no entanto, flutuavam ao sabor dos acontecimentos e da percepção assimilados pelos personagens. Definia-se uma cultura política que só a dinâmica do próprio processo histórico era capaz de revelar. ${ }^{1}$

Certas expressões podiam revelar a inserção dos agentes em uma cultura política historicamente constituída e as apropriações que dela faziam. É dentro desta perspectiva que buscaremos compreender as concepções do pensamento político dos atores sociais que atuaram no processo de constituição do partido liberal moderado no Ceará, entendendo que por meio da apreensão dos usos do vocabulário político é possível aprofundar os significados da cultura política liberal posta em prática.

Uma importante questão que o trecho citado nos traz é o caráter mutável da cultura política $^{2}$. Por estar associada não só a formas de pensar, mas às experiências sociais ${ }^{3} \mathrm{e}$ às conjunturas políticas, os significados dos conceitos vão tomando novas formas, apesar da permanência de antigas acepções em alguns momentos. A partir da transformação e conservação de alguns de seus aspectos na dinâmica histórica do Primeiro Reinado é que percebemos que a cultura política da Independência foi a base das percepções e ações políticas do período Regencial, sobretudo até a constituição definitiva dos partidos liberal e conservador.

O liberalismo embasou a constituição de uma cultura política que se espraiou por Portugal e Brasil durante o início dos anos 1820 e que esteve diretamente relacionada ao rompimento das relações coloniais, a partir de transformações que possibilitaram a ascensão de novas visões de mundo, concepções e práticas políticas. Um novo modo de conceber as fronteiras simbólicas internas de uma sociedade que passava a se forjar em torno de uma unidade territorial, possibilitando a constituição de uma nova ordem social e política para o Estado nascente. O liberalismo no Brasil deu suporte, assim, para se construir um Estado que atendesse aos anseios das elites diretamente ligadas ao processo de emancipação política, sem, no entanto, romper com a estrutura social marcada pela hierarquização entre seus habitantes e pela escravidão. 
Apesar desta perspectiva comum, um embate entre as elites, a partir dos seus diferentes projetos políticos, ocorreu ao longo do Primeiro Reinado. Seja nas instituições de representação política (como a Câmara e o Senado), na imprensa, através de insurreições que tentavam empreender um novo modelo de Estado ou mesmo através da atividade política fora dos muros institucionais, os agrupamentos foram se moldando a partir de afinidades múltiplas e quando o Imperador decidiu abdicar do trono em favor de seu filho, uma nova conjuntura se instalou em meio a uma crise. Os grupos mais fortes e que melhor se estruturaram (moderados, caramurus e exaltados) simbolizaram a apreensão e a vivência de valores ${ }^{4}$ diferenciados naquele contexto, o que gerou projetos políticos diferentes para a nação a partir de concepções divergentes do liberalismo. O grupo que saiu fortalecido na Câmara dos Deputados foi o dos liberais moderados, que segundo Marcello Basile era a "facção política" melhor organizada, a despeito de suas divergências internas.

Marco Morel $^{6}$ remonta a expressão "liberalismo moderado" dentro do mundo ibérico à Espanha das décadas de 1810 e 1820, quando vigorou a Constituição de Cádis.

\begin{abstract}
Tratava-se de um modelo inspirado nos Girondinos de 1791 (a revolução com o rei) e no Parlamentarismo inglês saído da "Gloriosa Revolução" de 1688; buscava-se um equilíbrio entre a autoridade monárquica e o Parlamento (como representante da soberania nacional); discutia-se sobre o alcance das prerrogativas monárquicas e a divisão de atribuições entre os Poderes: o rei controlaria os ministros e as Câmaras fariam as leis. ${ }^{7}$
\end{abstract}

Este modelo também prevaleceu em Portugal, segundo o mesmo historiador, sobretudo a partir de 1826. O trânsito de ideias e de pessoas que transmitiram a experiência ibérica para o Novo Mundo durante a Revolução do Porto de 1820 atuou decisivamente no predomínio desta orientação política na montagem do Estado brasileiro, seja no modo como se deu a Independência ou na feitura da Constituição de 1824. O cerne do pensamento era garantir reformas que atendessem às novas demandas, como a valorização da "representação política" materializada na instalação de uma câmara eletiva, atrelada à ideia de que a soberania estaria no povo, mas sem enfraquecer o poder monárquico. No Brasil, os liberais moderados começaram a estruturar uma aliança mais sólida com o início do funcionamento da Câmara dos Deputados em 1826 (a 1 1 legislatura), mas só consolidaram sua força política nas Regências, quando obtiveram maioria na Câmara e chegaram à administração do Império quando assumiram o Poder Executivo ${ }^{8}$.

Dentro deste contexto, nosso foco será entender as concepções políticas e sociais do partido liberal moderado do Ceará. Nesta província, uma questão que se impõe é que a 
formação dos agrupamentos se deu diferente do que houve na Corte, no sentido de não existirem três vertentes de pensamento delimitadas, sendo perceptível no início da década de 1830 a presença de duas. Uma era ligada aos restauradores que pregavam o retorno de D. Pedro I, com seus adeptos espalhados sobretudo pelo sul da província, na região do Cariri, tendo em Joaquim Pinto Madeira, membro da sociedade Coluna do Trono, seu grande expoente e líder de uma insurreição restauradora ocorrida logo após a abdicação do Imperador $^{9}$. A outra vertente se expressava pela existência de grupos de alianças que lutavam entre si pelo domínio dos instrumentos do Estado disponíveis, mas que possuíam como ponto comum uma orientação política semelhante sobre a organização da sociedade e do Estado: a visão do liberalismo moderado.

Aglutinavam-se em torno de um pensamento que preferia as reformas pautadas na manutenção da ordem e sem mobilização popular, como se tentou realizar no processo de independência e após a abdicação de D. Pedro I. Em uma proclamação feita pelo Vicepresidente da Província do Ceará, José de Castro e Silva ${ }^{10}$, em 13 de maio de 1831, informando sobre a Abdicação aos seus habitantes, alguns pontos merecem ser destacados para evidenciar o que queremos demonstrar. Louvando o fato ocorrido, ele anunciava a

completa Independencia do Brasil, o Principe Brasileiro está collocado no Throno dos Brasileiros. Dom Pedro Primeiro abdicou a Coroa e baqueou a Facção liberticida. O despotismo desappareceu com elle, e hoje só triunpha a Constituição. Tão glorioso acto não foi manchado com huma só gotta de sangue. [...] Appareceu a revolução e com ella a paz e a tranquilidade publica. Cearenses, reine esta entre nós e esperemos ordem da Regencia para solemnemente proclamarmos o Imperador Brasilero, o Snr. D. Pedro Segundo. ${ }^{11}$

Pouco tempo depois e seguindo esta mesma linha, outro Vice-Presidente, desta vez Miguel Antonio da Rocha Lima ${ }^{12}$, proferindo o discurso de abertura das sessões do Conselho Geral da Província em $1^{\circ}$ de dezembro de 1831, também expôs diversas feições do pensamento dos liberais moderados sobre a Abdicação:

[...] eu vos felicito por ver-vos pela terceira vez reunidos e já debaixo dos auspícios de um Governo puramente Nacional, no qual podem os Brazileiros depozitar a mais firme confiança e esperar que de accôrdo com os Augustos e Dignissimos Snrs. Representantes da Nação dê o mais amplo desenvolvimento aos preciosos germens da liberdade pratica, que se enserrão nas paginas da Lei fundamental. [...] Já não nos ameação os males que causa uma Côrte corrompida, Conselheiros e Ministros vendidos ao Poder. Já enfim vemos sobre o Throno Brazileiro um Monarcha nascido no nosso mesmo solo e os destinos do Imperio confiados a Cidadãos recommendaveis pelo seo patriotismo, e virtudes escolhidos pelo voto dos nossos Representantes. Tanto deve o Brazil ao progresso das Luzes, e da civilização e aos esforços dos nossos concidadãos Fluminenses, que valorosamente conquistarão a 
liberdade no glorioso Dia 7 de Abril! Tanto tem podido a influencia da Imprensa livre! $!^{13}$

Consolidava-se de fato para os moderados a Independência com a saída do Imperador D. Pedro I, de origem portuguesa, substituído por um monarca verdadeiramente nascido nestas terras. Na visão daqueles sujeitos e dos que de um modo geral dela partilhavam, a marca do processo foi o seu caráter eminentemente brasileiro, uma identidade que ainda carecia de maior robustez, mas que nas Regências encontraria seu desenvolvimento a partir da ação do Estado. A palavra "nosso", utilizada por Rocha Lima ao caracterizar o território em que nascera Pedro II, remete ao pertencimento comum entre monarca e povo, estabelecendo-se uma relação de proximidade oposta à que se fazia com Pedro I. O papel preponderante dado à Câmara dos Deputados, símbolo da representação nacional e marca de um governo constitucional pretensamente pautado na soberania popular, também foi destacado. Seria a Câmara a responsável por empreender a plenitude da "liberdade" prescrita pela Constituição de 1824. Ainda na fala de Rocha Lima, a Abdicação parece ser a culminância teleológica do progresso das luzes e da civilização, como se naquele momento estivessem aptos a enxergar as mazelas causadas por D. Pedro I, talvez uma tentativa de justificar o fato de até ali terem servido ao Imperador e mantido o status quo sem maiores contestações. Uma visão iluminista do triunfo das "luzes", que se pautava em um olhar otimista para o futuro.

Este processo fora assimilado por José de Castro e Silva como "revolução". Marco Morel $^{14}$ vê no uso deste termo, que não foi exclusivo dos moderados cearenses, uma estratégia para aquietar aos ânimos que se elevaram com a Abdicação. Engenhosamente, o Vice-presidente mencionou o processo como já encerrado e consolidado. A "revolução" do 7 de abril é entendida como o triunfo da liberdade sobre o autoritarismo do Monarca e sua eclosão não levou à desordem social, mas ao seu oposto. Isto foi possível a partir do momento em que a Constituição encontrou espaço necessário para ser integralmente seguida, ponto característico do discurso de ambos os Vice-presidentes. Constituição e liberdade aparecem assim como dois eixos seminais no pensamento liberal moderado.

A posição de José de Castro e Silva e Miguel da Rocha Lima era estratégica. Partia deles a tarefa primeira de abafar o ímpeto sedicioso que por ventura pudesse grassar na província. Tudo ocorrera sem derramamento de sangue, dizia José de Castro, a glória da "revolução" era posta aí. No entanto, as turbulências não se deram apenas nas ruas do Rio de Janeiro. Nas vilas de Crato, Jardim, Sobral e Lavras aconteceram movimentações (algumas 
armadas) que reagiam às notícias recém-chegadas da Abdicação e da ascensão de D. Pedro II, muito embora os fatos que se sucediam nestas localidades chegassem ao Vice-presidente com pouca concretude ou baseados em boatos, devido principalmente à distância e à dificuldade de comunicação entre a Capital e as vilas interioranas ${ }^{15}$. Mas, o que nos chamou a atenção nos ofícios que traziam aqueles relatos foi a expressão utilizada para se referir ao 7 de abril: regeneração política.

A Camara da Villa do Crato por occasião de terem chegado as noticias da nossa Regeneração Politica foi extraordinariamente convocada [...]. ${ }^{16}$

Das copias juntas dos officios da Camara Municipal da Villa das Lavras do Presidente da mesma, e do Juiz de Paz, assim como do Coronel Agostinho Jose Thomaz d'Aquino e dos que vão juntos a ella que todos forão apresentados em Concelho, e que na conformidade da sua resolução passo ás mãos o estado daquella Villa e os movimentos que nella tiveram lugar por occasião de ali chegarem as noticias da nossa gloriosa, e feliz regeneração politica. ${ }^{17}$

$\mathrm{O} \mathrm{Ex}^{\mathrm{mo}} \mathrm{S}^{\mathrm{r}} \mathrm{V}$. Presidente querendo fazer sciente ao Conselho do Governo a satisfatoria noticia que tem grassado da Glorioza Regeneração Politica e retirado [sic] do Principe D. Pedro ex Imperador do Brazil; me ordena que convide a V. S. ${ }^{r}$ para comparecer em Palacio esta tarde pelas 3 horas. ${ }^{18}$

A expressão é sugestiva quanto à forma de conceber aquele momento limite e inédito na história do Brasil. Dentro de sua trajetória política, ela fora primeiro utilizada durante o Vintismo ${ }^{19}$, com a intenção de inserir o movimento numa linhagem tradicional que buscava a plenitude dos direitos do cidadão português ao associar os acontecimentos de 1820 às vitórias alcançadas quando puseram fim à União Ibérica, relacionando a convocação das Cortes de Lisboa às de Lamego em 1640 - que resultaram numa constituição posta em execução por D. João IV. Era, portanto, a tentativa de retorno a um direito fundamental que estaria sendo violado pelo despotismo de D. João VI. Um processo que envolveu a seleção de fatos, datas e personagens que fizeram o elo entre passado e presente, entre a "origem" da nação e a Regeneração de $1820^{20}$. Regenerar estava, portanto, associado ao passado, com a ideia de introduzir novos valores através da "força transformadora" do constitucionalismo da década de 1820. Foi assim que a expressão também chegou a ser usada durante a Independência do Brasil, "quando o país se regenerava à medida que passava a nação autônoma e livre" 21 , adquirindo a partir daí uma outra perspectiva temporal, já que o passado era uma roupa que não servia mais.

No Período Regencial a expressão regeneração política adquire um sentido diverso daquele usado no Vintismo. Assim como na Independência, uma outra relação com o tempo é mobilizada pelos moderados. Não faria sentido o retorno ao passado, já que este 
guardava o tempo de espoliação, do domínio europeu sobre o Brasil e do despotismo de D. Pedro I. Não se queria andar para trás, esta intenção era resguardada aos caramurus. Pretender-se-ia caminhar adiante, seguindo o rumo trilhado pela moderação. A conjuntura política exigia dos moderados a desvinculação com o percurso histórico do país. Por suposto, regeneração política tinha uma postura voltada para frente, ao futuro. Regenerar era remodelar o passado.

A base do pensamento político do partido fincava-se, como mencionado, na ideia de moderação. O então deputado José Martiniano de Alencar ${ }^{22}$, em um discurso proferido na sessão de $1^{\circ}$ de maio de 1830 na Câmara dos Deputados, tratando sobre a validade ou não das eleições no Rio Grande de São Pedro do Sul, pediu coerência aos colegas da casa nos seguintes termos:

[...] necessario sim é fugir da idéa precipitada: muitas vezes o fogo da liberdade e o enthusiasmo patriótico nos conduzem a excessos, cumpre moderação, ela não é baixeza ou servilismo, é sim um demonstrativo de prudencia. ${ }^{23}$

A moderação se situava no centro de duas extremidades combatidas: o excesso de liberdade, que representava o perigo da subversão da ordem, e o apego tácito ao governo de D. Pedro I. Associava-se à cautela necessária para medir as ações em detrimento dos "entusiasmos", que deveriam ser mantidos sob controle. Marcello Basile situa o significado por trás desse termo na ideia de justo meio, "princípio aristotélico apropriado pelo constitucionalismo inglês do século XVII e, mais tarde, pelos doutrinários franceses da Restauração" 24 . Trazia a imagem de "equilíbrio racional" entre os limites encontrados no discurso de Alencar. Outro aspecto, destacado por Marco Morel $^{25}$ e observado no extrato acima é que moderação era comumente utilizada como comportamento, a despeito de uma posição política.

Moderação igualmente estava relacionada ao respeito à Lei. Sendo tangenciada pela legislação, a organização social deveria ser pautada pela Constituição. A opção por um regime governamental que se encaixasse nesta linha de pensamento foi o que norteou a defesa da monarquia constitucional. Na visão dos moderados, o governo de D. Pedro havia impedido sua plenitude. A partir do 7 de abril, uma nova possibilidade para o seu triunfo estava posta, sendo uma forma de governo capaz de "sustentar a integridade da nação e preservar os direitos dos cidadãos, de estabelecer o equilíbrio necessário entre ordem e liberdade" ${ }^{26}$, ou seja, resolveria as principais demandas vindas após a Abdicação. Mas há que pensarmos: quais direitos? Que cidadãos? Que ordem? Que liberdade? Para entendermos estes conceitos 
temos antes de entender um pouco sobre como pensavam a organização social e política nos parâmetros de uma monarquia constitucional.

Em 23 de abril de 1831, o jornal Semanário Constitucional - de cunho liberal moderado, ligado à família Castro $^{27}$ e tendo como principal redator Angelo José da Expectação Mendonça (Doutor Rapadura) ${ }^{28}$ - publicou um texto que tratava sobre o posicionamento que se deveria adotar em favor da monarquia constitucional no Brasil. Tomando três páginas daquela edição, o artigo começava lamentando que alguns redatores de jornais do Rio de Janeiro e Bahia, na intenção de livrar os cidadãos do "abismo" que os Ministérios tencionavam jogar o Brasil, acabavam levando-os a outro, ao da "anarquia" (possivelmente se referindo aos jornais de cunho exaltado). Acusava de tática criminosa o fato de quererem impedir a volta do absolutismo com a implantação da democracia - alegava que este modelo era inconcebível para a sociedade brasileira devido aos meios de que dispunham, apesar de não especificar que meios eram estes -, bem como repudiava a alteração da organização política fundada no aspecto "Monarchico-Constitucional-Representativo", cuja base era o pacto entre a nação e seu "chefe" (este termo já revela o forte papel do Imperador nesta organização), princípios essenciais para a Constituição de 1824. Era preciso impedir que os partidos surgidos em diferentes regiões do país tomassem conta da situação e tornasse “odiosa a Liberdade". Continuava dizendo que para alguns o atual sistema de Governo só servia a poucos, o que na ótica do redator estava errado, já que nos últimos sete anos tinham avançado nas "luzes" e na "civilização", a despeito dos "mandões" e "inimigos da Liberdade" (aqui fazia referência aos Ministros e, cremos, ao ex-Imperador). A tentativa de se instaurar uma democracia ou confederação naquele momento não faria bem ao país e serviria para "embaraçar a marcha e progresso da nossa liberdade". O exemplo dos Estados Unidos se justificava pelo "estado de cultura mental em que estão" e pelo tempo de desenvolvimento de suas instituições, o que acabava justificando a opção da monarquia constitucional pelos brasileiros como forma de preparar o país para um modelo mais avançado, que teria a democracia norte-americana como ponto de chegada ${ }^{29}$.

A partir deste artigo é possível concebermos o modelo de administração do Estado defendido pelos moderados da província (formulações semelhantes eram veiculadas em outro periódico do mesmo período, como o Cearense Jacauna, de mesma orientação política). A Constituição era o elemento articulador das ações moderadas, neste sentido a questão que eclodiu após o 7 de abril foi a sua má execução até ali. Pensamento semelhante foi analisado por Marcello Basile ${ }^{30}$ nos jornais moderados da Corte, onde constatou que até a Abdicação 
este agrupamento defendeu a centralização em torno do poder central, já que as diretrizes constitucionais contemplavam todos os anseios da sociedade e da gestão política do Império, não necessitando de nenhuma intervenção. Entretanto, foi após a saída de D. Pedro I que os moderados passaram a olhar mais atentamente para o projeto de reforma constitucional que tramitava pela Câmara dos Deputados, conhecido como projeto Miranda Ribeiro, a partir do qual foi materializado o Ato Adicional de 1834.

A monarquia constitucional surgia, assim, como a materialização da moderação enquanto regime de governo, “[...] estratégia de hegemonia, histórica e politicamente datada [...]"31 durante o período da Independência e articulada durante a Regência como sistema melhor adaptado à realidade nacional. Além disto, a defesa de uma monarquia demarcava a concepção sobre o posicionamento que o Brasil deveria ter dentro do contexto sul-americano, diferenciando-se do caminho que tomaram os Estados Nacionais vizinhos, que se tornaram repúblicas. A valorização daquele modelo governamental se tornou uma estratégia para que os moderados se mantivessem no domínio da situação. Elaborado e propagado o regime de governo mais condizente com a realidade brasileira (na visão dos moderados), era necessário, em seguida, empreender a delimitação da "ordem social", que tentaria assegurar a posição privilegiada da elite econômica e política ${ }^{32}$. Aqui entra a ideia de liberdade para este grupo.

Percebamos que no artigo publicado no Semanário Constitucional anteriormente descrito havia um posicionamento diante da apropriação considerada errônea de liberdade: era preciso impedir que os diversos partidos surgidos em diferentes regiões do país tomassem conta da situação e tornassem "odiosa a Liberdade", o que demonstra que existia uma preocupação em delimitar um reto sentido para este conceito. Na busca por esta delimitação, era necessário que se definissem os parâmetros normatizadores da vida social dos que habitavam o território brasileiro, estabelecendo as práticas socialmente aceitas e suas infrações. Dois elementos foram importantes como balizadores da ordem social para os liberais moderados: o Código Criminal de 1830 e o Código do Processo Criminal de 1832.

Desde o início da atividade legislativa no Brasil, em 1826, quando entrou em exercício a Câmara dos Deputados, viu-se a necessidade de se compilar um código de leis criminais, pois ainda se utilizavam das Ordenações Filipinas como base para as ações penais. Foi então que teve início um longo debate sobre a formatação de um código criminal brasileiro, sendo apenas na segunda legislatura, iniciada em 1830 e cuja maioria dos assentos fora ocupada por liberais moderados, que finalmente se chegou a um projeto definitivo, aprovado pela Câmara e pelo Senado e sancionado pelo Imperador em 16 de dezembro. 
Baseado no projeto apresentado por Bernardo Pereira de Vasconcelos (liberal moderado), foi considerado à época um moderno instrumento penal. Além de prescrever o rol de crimes que poriam limites às ações dos indivíduos, estava atento a inovações quanto ao uso da força de trabalho como medida penal e a tipificação de crimes públicos, tais como: contra a integridade da nação, contra o chefe de Estado e contra a forma de governo constitucionalmente estabelecida, daí as constantes queixas encontradas nas fontes anteriormente citadas para se tentar enquadrar as alegadas tentativas de transformar o Brasil em república ou em Estado despótico como crimes ${ }^{33}$.

O Código do Processo Criminal de 1832, inserido no âmbito das reformas constitucionais empreendidas pelos moderados ao assumirem o poder, foi o meio pelo qual se tentou dar maior celeridade e desembaraço às ações penais e expressava o anseio liberal da autonomia judiciária. Ele prescrevia a organização do aparelho judiciário nos municípios, atribuindo novas diretrizes aos juízes de paz, estabelecendo a estruturação dos distritos, termos e comarcas, criando o corpo de jurados encarregados de julgar os crimes e instituindo o habeas corpus. Também teve a função de normatizar as práticas judiciárias nas mais diversas localidades do Império, evitando-se desvios ou excessos por parte dos representantes do Judiciário.

Deveria, portanto, haver uma ação conjunta entre o Código Criminal de 1830 e o Código do Processo de 1832 para racionalizar a atuação dos juízes e demais partes do corpo judiciário local. Entretanto, para além de mecanismos que tentavam resguardar a segurança individual, os direitos do cidadão, bem como a integridade do Estado, os dois códigos podem ser vistos como instrumentos de afirmação do sentido de liberdade do liberalismo moderado, a delimitação das fronteiras simbólicas da liberdade. O grupo político por trás destas elaborações tentava construir uma ordem social, ou pelo menos realizar alguns ajustes na estrutura do Estado, que se adequasse ao modelo de sociedade idealizado. Não foi à toa que logo após a Abdicação, leis aditivas ao Código de 1830 foram implementadas, no intuito de aumentar o rigor das punições a crimes cometidos por "vadios", ajuntamentos ilícitos e, em 1835 , delitos cometidos por escravos ${ }^{34}$. Não é possível desvincularmos a experiência social coletiva da elaboração dos instrumentos normativos, que naquele contexto representavam a materialização das concepções de organização social das camadas dirigentes. A lógica era de que o Estado seria a principal via delimitadora das práticas de sociabilidade legítimas e transgressoras. 
Os partidários da moderação se autodenominavam, entre os artigos publicados em jornais, como defensores da "causa da Liberdade" e justamente por meio dos periódicos podemos enxergar algumas relações estabelecidas em torno deste conceito. No Cearense Jacauna de 17 de outubro de 1832 - jornal de cunho liberal moderado, cujo redator principal era José Ferreira Lima Sucupira ${ }^{35}$-, comentava-se a respeito da repressão aos envolvidos na rebelião de Pinto Madeira, onde o mote do texto era a ação desmedida do Comandante Geral Francisco Xavier Torres (um dos líderes das tropas legalistas), que mais parecia um "conquistador", nas palavras do redator, desrespeitando o direito de propriedade de alguns moradores das cercanias da vila do Crato (relata a subtração de plantações de cana para serem vendidas na vila, por exemplo) e isto contribuía para "os povos ainda não terem gostado dos saborosos, e inapreciáveis frutos da Constituição, e de não estar ja o sistema firme, e inabalavel" 36 . Diante das querelas que se instalaram entre os juízes e as tropas do Comandante Torres, o redator acreditava que isto só iria fortalecer os "inimigos da causa da Liberdade",

\begin{abstract}
Mas se cada hum Liberal, quando he incumbido do desempenho de qualquer funcção, fosse hum regido observador da lei, fosse huma cópia fiel do Liberalismo, desse a exemplar convicção, que a Lei pune com igualdade a quem a infringe, embora pertença a esta ou aquella classe, que o direito de propriedade he sagrado, que ninguém pode ser privado della senão nos casos, e pelo modo marcado na Lei, que a segurança individual he garantida, que a Religião do Estado he respeitada, e que a forma do Governo só legalmente pode ser alterada; a muito, que os inimigos da Liberdade, e da Patria estariam descorçoadas [...]. ${ }^{37}$
\end{abstract}

Percebemos que a relação com a Lei tem dois vieses: ela é tanto delimitadora da liberdade, quanto balizadora do liberalismo. A lei origina a liberdade, a igualdade entre os cidadãos e os direitos fundamentais. Liberalismo se estabelece enquanto comportamento, em seguir o rumo traçado pela norma, meio através do qual se chegaria a um desenvolvimento que possibilitaria a plenitude da felicidade em todo o país. Na verdade, é possível entender tal apropriação do conceito de liberalismo como maneira de demonstrar a importância do mecanismo constitucional para a organização da vida social e para a construção de uma ordem. Esta seria a conjuntura ideal para que os moderados pudessem se estabelecer no poder sem a ameaça de movimentos populares que pudessem minar a estrutura da sociedade (escravista e hierarquizada) e para consolidar sua posição de domínio sobre o campo político nacional pela via da administração do Estado.

A retidão no comportamento dos liberais seria instrumento pedagógico para o enraizamento deste ideário na população. O problema se daria pelo desvio de comportamento daqueles que mais necessitariam exercê-lo corretamente: os funcionários públicos, que tinham 
de seguir a cartilha designada pelos moderados e garantir uma unidade de ações. Os interesses particulares não deveriam se sobrepor ao regramento das ações liberais, já que eram eles os responsáveis por levar esta diretriz ao interior do território nacional.

Igualdade perante a lei, garantia da propriedade privada e da integridade dos cidadãos, respeito ao catolicismo e governo guiado pela Lei: isto garantiria a liberdade. Liberalismo/moderação/Lei/liberdade, esta era a relação indissociável que se estabelecia no pensamento moderado e para mantê-la era necessário controlar aquilo que poderia ameaça-la, aí entram as medidas punitivas normatizadas pelos códigos de 1830 e 1832. Foram a expressão das negociações e articulações entre as elites dirigentes. Instituíram não só os limites da liberdade a partir do instante em que se definiam as transgressões, como as medidas adotadas pelo Estado contra os transgressores, legitimando a repressão em defesa da ordem social e da liberdade por eles construídas.

As medidas legais e a pedagogia liberal, através dos jornais e do comportamento dos representantes do Estado, garantiriam uma ação conjunta para instituir tal modelo de ordem social. Se a soberania residia no "povo", que elegia os seus representantes para a Câmara dos Deputados, estes por sua vez construíam os mecanismos legais que garantiriam o ordenamento a ser seguido pelo mesmo "povo", consolidando a hierarquia social e garantindo o poder do Estado sobre a população. Este também se constituía a partir destas ações, normatizando práticas e saberes que definiriam na sociedade as divisões simbólicas entre o mundo da ordem e da desordem. Os moderados moldaram a liberdade que lhes convieram, atentos aos "perigos" que rondavam o modelo de sociedade segregada e escravista. Liberdade significava muito mais um modelo de regramento social do que um direito de livre iniciativa dos indivíduos. "O excesso de liberdade era, então, tudo aquilo que ultrapassava essa medida legal [...]"38. Definia-se o conceito, portanto, como liberdade constitucional ${ }^{39}$. Livre era aquele que seguia a trilha da Lei, ou seja, uma liberdade teoricamente fundada por um contrato social.

O Estado Imperial, a partir do momento em que legitimou um modelo de sociedade que se constituía desde a Colônia ${ }^{40}$, construiu um sentido de liberdade voltado aos interesses daqueles que compunham as camadas socialmente superiores e que não desejavam ver ampliada os direitos políticos prescritos pela Carta de 1824, devido a uma série de temores com a população social e economicamente inferior. Deste modo, é possível entendermos outro aspecto do ideário liberal moderado: o cidadão. 
A concepção de cidadania no Brasil teve origem na tradição portuguesa, que influenciou a feitura da Carta Magna de 1824 através do legado do movimento vintista. As transformações ocorridas na segunda metade do século XVIII (Iluminismo, independência das colônias britânicas e Revolução Francesa) propiciaram em Portugal a incorporação de um novo entendimento sobre o direito e a participação dos indivíduos na sociedade, que se mesclaram a aspectos sociais e políticos permanecidos do Antigo Regime lusitano.

Jose Murilo de Carvalho concebe este conceito a partir de três tipos de direitos: civis, políticos e sociais. "Direitos civis são os direitos fundamentais à vida, à liberdade, à propriedade, à igualdade perante a lei”, tendo por objetivo a liberdade individual; direitos políticos "se referem à participação do cidadão no governo da sociedade", tendo por finalidade a noção de autogoverno; direitos sociais "incluem o direito à educação, ao trabalho, ao salário justo, à saúde, à aposentadoria", logo requer uma "eficiente máquina administrativa do Poder Executivo" ${ }^{41}$ e sua plenitude culminaria na justiça social. A aquisição destas três ordens de direitos garantiria uma cidadania plena, entretanto sua conquista se deu aos poucos, ao longo do processo de formação das nações e no Brasil não foi diferente. Na Constituição de 1824, como constatou o mesmo autor, os direitos políticos precederam os civis e sociais. Estabeleceu-se a diferenciação entre brasileiro e cidadão brasileiro e de antemão excluíam-se índios e escravos do segundo entendimento.

No debate político brasileiro do século XIX, a diferenciação entre cidadãos portadores de direitos políticos e aqueles apenas titulares de direitos civis será elaborada a partir da distinção entre cidadão ativo e passivo, originário do constitucionalismo francês. ${ }^{42}$

Aos cidadãos ativos, homens livres, com idade igual ou superior a 21 ou 25 anos (dependendo das especificações contidas na Constituição), nascidos no Brasil ou naturalizados, com renda mínima anual de cem mil réis, assegurava-se o direito ao voto nas eleições primárias $^{43}$; aos que não se encaixavam em qualquer dos requisitos prescritos na Carta Magna ${ }^{44}$, a participação política no processo eleitoral era vetada. A fronteira era estabelecida, portanto, a partir do aspecto censitário. Contudo, Antonio Edmilson Rodrigues, Francisco Falcon e Margarida Neves ${ }^{45}$ entendem que este aspecto escondia a real baliza da delimitação: a propriedade (de terras e escravos), constituindo-se o que chamaram de "metáfora da propriedade". No Brasil do século XIX, é ela "o elemento que define a cidadania, que personaliza o cidadão distinguindo-o do simples indivíduo [...]” (p. 15, grifos dos autores). Como exemplo, já que a Guarda Nacional era seu objeto de estudo, citam o caso 
dos Conselhos de Qualificação desta corporação, comissões responsáveis por avaliar se os indivíduos tinham ou não condição de nela ingressar. Lembrando que a Guarda Nacional se utilizava do mesmo princípio censitário que norteava a definição de cidadão da Constituição, os autores mencionam o fato de que na prática bastava qualquer comprovação de que o indivíduo era proprietário, até mesmo a palavra de um senhor local, como pressuposição de que se teria a renda mínima exigida. A propriedade era assim a verdadeira definidora da cidadania.

Nesta linha de raciocínio é que Ilmar Mattos enxerga a relação que se estabelecia entre propriedade e liberdade: “[...] os atributos de liberdade e propriedade existiam de modo articulado nesta sociedade, de tal forma que o último fundava o primeiro [...], é possível perceber pela recorrência ao próprio texto constitucional de 1824 "46. A partir desta premissa, ele compreende os cidadãos não-ativos como "proprietários de suas pessoas" e os ativos como aqueles "que são também proprietários de outrem [escravos]" (p. 129). Se na França a distinção pautada na renda e na propriedade representava o "sinal do trabalho, do talento, do mérito, como uma presunção de que os eleitores que tenham maior independência terão disponibilidade para se informarem e poderão emitir opiniões mais fundamentadas" ${ }^{\text {, }}$, no Brasil, este critério podia até ter implícitas estas premissas, mas visava principalmente a preservação de uma estrutura social moldada desde o período colonial.

Entre os cidadãos ativos se originava ainda uma outra divisão: votantes, eleitores e elegíveis. Aqueles participariam das eleições primárias, como já mencionado, e seriam responsáveis por escolherem os eleitores. Estes últimos deveriam ter renda mínima anual de duzentos mil réis e votariam diretamente nos deputados e senadores. Os elegíveis seriam os que poderiam candidatar-se a um destes dois cargos. Tinham de atender a alguns prérequisitos, como ter renda anual mínima de quatrocentos mil réis para deputados e oitocentos mil para o caso dos senadores, além de pelo menos quarenta anos de idade neste último caso. Tal gradação reproduzia, assim, a hierarquia social. Corroborava para a manutenção de uma realidade social já existente, que privilegiava os grandes proprietários na participação política, legitimada pela Constituição de 1824. Se pensarmos conforme Ilmar Mattos, no sentido de conceber o conjunto dos cidadãos ativos como confundido com a própria sociedade política ou o mundo do governo (enquanto os cidadãos não-ativos formariam a sociedade civil), podemos aventar, contudo, que a partir da hierarquização interna exposta, o governo do Estado não seria acessível ao conjunto dos cidadãos ativos, constituindo-se antes num lócus ao alcance apenas dos cidadãos mais destacados econômica, política ou socialmente, numa 
concepção com raízes iluministas (corroborada pela própria Constituição) de que aos mais capazes, aos detentores das Luzes, caber-se-ia guiar os destinos da nação.

Esta concepção de cidadão foi reforçada pelos liberais moderados através de diversos mecanismos, seja por discursos veiculados na imprensa ou pelas instituições criadas ao assumirem a direção do Império nas Regências, como foi o caso da Guarda Nacional ${ }^{48}$. Dirimida pelos artigos publicados em jornais como Cearense Jacauna, Semanário Constitucional ou no Correio da Assembleia Provincial, percebe-se que tal ideia de cidadão ou cidadania estava sempre relacionada ao respeito ou ao conhecimento da lei/Constituição. Neste sentido, pode-se estabelecer outra relação: ser moderado nas ações políticas era ser também cidadão. Como o pensamento moderado se articulava em torno da construção de uma ordem social baseada nos aspectos anteriormente mencionados, a categoria de cidadão era estabelecedora da clivagem entre o mundo da ordem e da desordem. Encaixar-se naquela categoria já era predisposição para se inserir no mundo da ordem e no dever de mantê-lo, além de demarcar o posicionamento ocupado na sociedade escravista.

A condição de cidadão que encontramos veiculada nos jornais era quase sempre reforçada a partir do posicionamento diante do povo. Este parece ser um dos conceitos que mais idas e vindas possuiu. Sua trajetória é marcada por uma guinada que consistiu em deixar de se associar ao terceiro estado do Antigo Regime (a plebe) e passar a representar o conjunto dos cidadãos de uma nação, a partir da influência das revoluções do final do século XVIII, representando a entidade detentora da soberania. Entretanto, não perdeu a identificação com as classes menos favorecidas e desprovidas economicamente, assim, ora associava-se a povocidadão, ora a povo-plebe ${ }^{49}$. Durante a Independência brasileira, logo que o temor da participação popular emergiu entre a elite que guiou aquele processo, "povo" passou a se relacionar aos homens bons, ou cidadãos, mas ainda assim a ambivalência do termo persistiu até o período que aqui analisamos.

Se quanto ao uso do termo cidadão, percebemos estar ele sempre associado aos preceitos constitucionais, com o termo povo, no sentido de povo-cidadão, não era diferente. Assim encontramos, por exemplo, num ofício do Chefe da Guarda Nacional da vila de Aracati, Silvestre Ferreira dos Santos, ao Presidente José Martiniano de Alencar, publicado no Correio da Assembleia Provincial de 21 de janeiro de 1837. Nele, o oficial relatou o que ocorrera nas últimas eleições, acusando o juiz de paz que presidiu a mesa paroquial de ter incitado tensões. Escreveu: 
[...] participava ter o actual Juiz de Paz desta Villa Manoel Dias Martins, pretendido organisar huma meza Parochial, a seu bel prazer sem attender a recuza do povo que avia concorrido para prestar seus votos e que por esta recuza o mesmo Juiz de Paz desolvêra [dissolvera] o congresso do Povo por retirar-se sem a nada querer attender mais do que a seu caprixo. ${ }^{50}$

Ambos os termos atrelavam-se à ideia de povo-cidadão, ligados ao conjunto dos cidadãos que tinham direito à participação política através do voto. Povo-cidadão era o lugar da soberania política ${ }^{51}$, aí deveriam reinar a igualdade e a liberdade constitucionais. Este povo representava o mundo do governo e da ordem e o fato relatado se agravava ainda mais devido ao juiz ter ido de encontro ao direito de participação política. Essa concepção se opunha à representação de povo-plebe.

A ideia de distinção que a categoria cidadão pressupunha influenciava no modo de agir dos indivíduos, "são essas representações que acabam por dirigir a conduta social, porque é por meio delas que cada indivíduo ou grupo social toma consciência de sua relação com os demais e com o próprio mundo" $" 52$. A plebe era formada por aqueles cuja posição social os punha naturalmente fora dos limites do mundo da ordem. Alvos da pedagogia liberal, deveriam ser controlados e pressionados a desenvolver atividades econômicas, já que através do trabalho poderiam se fixar em determinado lugar e estariam previamente fora do âmbito criminal da vadiagem ${ }^{53}$. No Correio da Assembleia Provincial de 14 de janeiro de 1837, por exemplo, publicou-se um ofício endereçado ao Presidente Provincial José Martiniano de Alencar, do juiz de paz da vila de Aracati, Manoel Dias Martins, onde relatava sua versão sobre o "quebra-quebra" ocorrido na eleição da vila, apontando os culpados e suas ações durante o ocorrido. Neste relato é possível observar a relação estabelecida com o povo-plebe:

Cançados de deprimirem aos amantes da ordem, ora por si, e já por seus emissários fasião chegar ao conhecimento do povo ignorante, que éramos inimigos da Religião, e quantos votassem ficarião sendo Mações e ora publicamente diziam que quem votasse em nós ficavão captivos! $!^{54}$

Afora o teor das acusações - exemplo de ações que marcavam os pleitos no século XIX-, duas categorias foram colocadas em posições divergentes: amantes da ordem e povo ignorante. Por amantes da ordem devemos entender os partidários do juiz de paz e no ofício foram postos em posição socialmente elevada, como se constituíssem uma camada de liderança política ou potencialmente propensa a ter esta função, daí os ataques de rivais no intuito de enfraquecê-los, donde se pode constatar que as ações giravam em torno das disputas pelos espaços de poder cujo acesso se dava pelo processo eleitoral. $\mathrm{O}$ intuito do juiz de paz 
era demonstrar a Martiniano de Alencar que eles eram os seguidores da lei, a despeito do Chefe da Guarda Nacional e seus aliados, que segundo o juiz causaram a desordem. Diante disto, o autor do ofício explora a atuação perniciosa dos rivais e é neste ponto que aflora a outra concepção de povo que buscamos evidenciar.

O povo ignorante situa-se no entendimento de povo-plebe e se observarmos a construção feita em torno dele, caracterizava-se por englobar uma população pretensamente receptível a qualquer tipo de boato, aqueles que não agiam por si só, que não tinham capacidade intelectual para administrar seus próprios atos, portanto não deveriam ter a legitimidade da participação política. O perigo estava aí. A plebe, na visão destes sujeitos, era manipulável, facilmente arregimentada em favor de qualquer opinião vinda de alguém que estivesse em posição social superior. Não é difícil encontrar referências disto na documentação oficial ou na troca de correspondência privada, sobretudo quando tratavam das mobilizações feitas pelos líderes da revolta de Pinto Madeira, na vila de Jardim.

Em 25 de junho de 1831, o Vice-presidente da província José de Castro e Silva enviou um ofício ao Ministro da Justiça Manoel José de Souza França dizendo ter recebido notícias desagradáveis da Câmara daquela vila, onde Pinto Madeira e outros indivíduos queriam se opor à aclamação do Imperador D. Pedro II. Apesar de a Câmara de Jardim asseverar que iria cumprir as ordens do Governo, outras notícias diziam que "immenso povo daquelle centro tem corrido para dita Villa a unir-se ao Coronel Pinto Madeira"55. Em virtude da ameaça de estarem armados e de se mobilizarem também em torno das vilas de Crato e Icó, o governante mandou o Comandante das Armas para "armonizar [sic] e tranquillisar aquelles Povos por meio de brandura e só em ultimo caso com o emprêgo das armas para fasellos entrar nos seos diveres [sic] e suplantar a anarchia" ${ }^{\natural 6}$. O sentido empregado era sinônimo de população, mas também estava presente o de povo-plebe. Manipulável diante daqueles que se situavam em posição superior na sociedade, era a plebe a massa que compunha os bandos armados liderados por senhores locais, como disse o Vice-presidente Miguel da Rocha Lima na fala de abertura das sessões do Conselho Geral em $1^{\circ}$ de dezembro de 1831. Ele acreditava que

[...] só a prezença de bayonetas disciplinadas e dispostas a apoiar a liberdade legal tem podido conter a dezenfreada licença de huma populaça rude $e$ indômita, avezada de muitos tempos ao assassínio, e a todos os crimes animados pela impunidade, e pela desmoralização de indivíduos que costumam aggregar a si grandes séquitos de facinorosos, com que se fazem o terror das authoridades locaes, e dos cidadãos pacíficos, que dezarmados e sem a força, que resulta de regularidade, e disciplina, não ouzão arrostar esses bandos de homens, que sem alguma coisa á 
perder, e sem ter outros vínculos na sociedade se não os da própria existência, não duvidão arriscal-a a cada momento e as vezes por bem diminuta paga. ${ }^{57}$

"Povo ignorante", "populaça rude e indômita", plebe, enfim, em todos os casos é possível estabelecer relações que ligam as populações pobres livres ao âmbito criminal, além da fronteira simbólica com a liberdade constitucional, ou "liberdade legal", nas palavras de Rocha Lima. Povo-plebe era um dos alvos principais do processo de imposição da ordem liberal. Deveriam ser harmonizados e tranquilizados não só em momentos de insurreições. Era quase parte de sua natureza a subversão ("avezada de muitos tempos ao assassínio"), situando-se no campo oposto aos dos "cidadãos pacíficos", "amantes da ordem", herdeiros dos homens bons do período colonial. Havia a necessidade de impô-los a "liberdade legal", o domínio das leis. A violência era monopólio do Estado, legítimo detentor do livre uso das armas de fogo. A fluidez dessa população, que não estabelecia vínculos em lugar algum, na visão destes senhores, era perniciosa aos interesses dos que governavam o Império e pretendiam lograr uma ordem social que lhes favorecesses. A plebe era livre, o que a diferenciava dos escravos. Mas, sua liberdade deveria ser suplantada em benefício da que se constituía pelas mãos da elite política, sobretudo dos liberais moderados. A intensão que os dirigentes tinham era a de situar povo-plebe no mundo da desordem, a partir da associação estabelecida com séquitos armados, assassinatos, anarquia, subversão, indisciplina, ataque à propriedade privada, ignorância intelectual etc. Como ponderou Ilmar Mattos, "No entender de muitos dos componentes do mundo do governo, a desordem das ruas contrastava vivamente com a ordem da casa" ${ }^{, 58}$, local da soberania do cidadão, da liberdade constitucional e da defesa da propriedade privada. Localizavam sua posição na sociedade para reforçar a estrutura hierarquizada ${ }^{59}$.

Descaracterizar socialmente tais camadas, minando toda sua potência enquanto força social, deslegitimando sua capacidade articuladora e seu poder de entendimento da realidade social era necessário para legitimar a incursão do Estado sobre elas. O medo da participação popular nas movimentações sociais era ameaçador para a elite política, social e econômica, devido ao medo da subversão do status quo. Tal ameaça não pairava apenas no imaginário das elites, ela se concretizava na vivência social, basta ver a presença desta população pobre em revoltas que permearam as Regências, espaço encontrado para reivindicar seus anseios. No próprio processo de Independência, por exemplo, houve uma intensa atividade dos pobres livres e escravos em melhorar sua condição de vida, influenciados, segundo Gladys S. Ribeiro ${ }^{60}$, pela difusão do ideal de liberdade que marcou 
aquele momento. Importante é que não percamos de vista que tais populações possuíam reivindicações próprias e interpretações diferenciadas dos princípios norteadores do liberalismo.

O liberalismo no Brasil foi, assim, uma filosofia que permitiu a inauguração de um Império na antiga colônia, instaurando transformações no plano econômico e político, mas que respaldava um modelo de sociedade excludente, com uma concepção de liberdade legitimadora do controle sobre a sociedade, sobretudo das camadas baixas. A partir do momento em que a Lei delimitou uma concepção de liberdade, ela legitimou a ação repressora do Estado sobre toda e qualquer manifestação que fosse interpretada como transcendente à ordem constituída. Para garantir a unidade na execução do projeto político do partido liberal moderado, era necessário o apoio vindo das diversas províncias. A constituição do partido moderado na província do Ceará foi, então, crucial para aquele contexto, para a afirmação da hegemonia liberal na província - utilizando-se aqui da linha de pensamento de Wlamir Silva $^{61}$. A chegada de Alencar à presidência do Ceará, nomeado ainda durante a última Regência Trina, demonstrou o prestígio e a confiança nele depositados, mas, além disto, acabou representando um esteio no fortalecimento do partido na província e uma base de apoio à Regência do padre Diogo Antônio Feijó, que assumiu o cargo em 1835. O partido perdurou até 1837, quando Feijó renunciou, o partido moderado se esfacelou na Corte (e consequentemente na província) e o Regresso conservador assumiu a administração imperial com Araújo Lima na Regência. Entretanto, analisar o período de formação do partido liberal moderado é buscar compreender, dentre outros aspectos, as formas de articulação política daqueles sujeitos, os mecanismos de unidade utilizados neste processo e os instrumentos empregados no enfrentamento com os opositores. É neste contexto que análise das categorias presentes na concepção liberal moderada se faz necessária.

Sob diversos suportes (ofícios, publicações, proclamações) eram publicizadas tais categorias. Os jornais, contudo, guardavam uma função mais peculiar, justamente por ser a principal ferramenta de propagação destas ideias, através da sua circulação entre a população de diversas partes da província (ou fora dela). Eles podem ser visto como um produto do campo político, utilizando-nos do pensamento de Pierre Bourdieu, mais especificamente como um "instrumento de percepção e expressão do mundo social" e um dos objetivos das disputas do campo político é o controle, pelos agentes em conflito, dos instrumentos que compõem este mesmo campo, como por exemplo, a dominação sobre os "instrumentos de 
percepção e expressão do mundo social”, o poder de transformar ou de manter o mundo social, o status quo, "conservando ou transformando as categorias de percepção desse mundo" ${ }^{62}$. Portanto, ao encararmos os jornais como um destes instrumentos, estamos afirmando que a produção de verdades por meio dos periódicos era essencial para as disputas que se travavam naquele campo, na tentativa de legitimação daquilo que expressavam: "a passagem do implícito ao explícito, da impressão subjetiva à expressão objetiva, à manifestação pública num discurso ou num ato público constitui por si um ato de instituição e representa por isso uma forma de oficialização, de legitimação" ${ }^{63}$. Era uma ferramenta para se criar um senso comum que respaldasse a hierarquização desejada do mundo social, para tornar hegemônica a sua visão de mundo e, portanto, servia para difundir as bases ideário liberal moderado frente às concepções que com ele rivalizavam, como por exemplo, a dos restauradores e, posteriormente, a dos opositores ao partido liberal moderado ${ }^{64}$. É neste contexto que se inscreve a importância da análise das concepções liberais moderadas para compreender o processo de constituição do mesmo partido e dos significados da cultura política liberal posta em prática.

\section{Notas}

${ }^{1}$ NEVES, Lúcia Maria Bastos Pereira das. Corcundas e constitucionais: a cultura política da Independência (1820-1822). Rio de Janeiro: Editora Revan/ FAPERJ, 2003. (grifo nosso)

${ }^{2}$ Ver MOTTA, Rodrigo Patto Sá. Desafios e possibilidades na apropriação de cultura política pela historiografia. In: _. Culturas políticas na História: novos estudos. Belo Horizonte: Argvmentvm Editora, 2009, p. 13-38 e NEVES, Op. Cit.

${ }^{3}$ Ver THOMPSON, E. P. A miséria da teoria ou um planetário de erros: uma crítica ao pensamento de Althusser. Tradução de Waltensir Dutra. Rio de Janeiro: Zahar Editores, 1981.

4 “'Os valores não são 'pensados', nem 'chamados'; são vividos, e surgem dentro do mesmo vínculo com a vida material e as relações materiais em que surgem as nossas idéias. São as normas, regras, expectativas etc. necessárias e aprendidas (e 'aprendidas' no sentimento) no 'habitus' de viver; e aprendidas, em primeiro lugar, na família, no trabalho e na comunidade imediata”. THOMPSON, Op. Cit., p. 194.

${ }^{5}$ BASILE, Marcello Otávio Neri de Campos. O Império em construção: projetos de Brasil e ação política na Corte Regencial. Tese (Doutorado em História Social) - Instituto de Filosofia e Ciências Sociais, Universidade Federal do Rio de Janeiro, Rio de Janeiro, 2004.

${ }^{6}$ MOREL, Marco. As transformações dos espaços públicos: imprensa, atores políticos e sociabilidades na Cidade Imperial (1820 - 1840). $2^{a}$ ed. São Paulo: Editora Hucitec, 2010.

${ }^{7}$ Idem, p. 118.

${ }^{8}$ Idem, cap. 3.

9 A respeito da Sedição de Pinto Madeira, cf. FELIX, Keile Socorro Leite. "Espiritos inflamados": a construção do Estado nacional brasileiro e os projetos políticos no Ceará (1817 - 1840). Dissertação (Mestrado em História Social) - Centro de Humanidades, Universidade Federal do Ceará, Fortaleza, 2010.

${ }^{10}$ Membro de uma das famílias mais poderosas do período imperial, marcada pelo domínio de diversos cargos burocráticos na província e originária de Aracati, no litoral leste do Ceará, José de Castro e Silva compôs o partido moderado no Ceará após a sua constituição. Ocupou cargos importantes durante os primeiros anos do período imperial (sua família apoiava a administração de D. Pedro I): fora capitão-mor, secretário de presidente de província, conselheiro do Governo, vice-presidente da província e deputado provincial, posteriormente. Cf. 
STUDART, Guilherme. Diccionário bio-bibliográphico cearense II. Edição fac-simile. Fortaleza: Iris; Secult, 2012 (1913), p. 105.

${ }^{11}$ UMA PROCLAMAÇÃO do Vice-Presidente José de Castro Silva. Revista do Instituto do Ceará, t. XVI, 1902, p. 280.

12 Assim como José de Castro e Silva, também se alinhou ao partido moderado do Ceará quando de sua constituição. Sua trajetória também é marcada pela ocupação de diversos cargos burocráticos durante as primeiras décadas do Império: ouvidor da Comarca de Fortaleza, juiz de fora, juiz de paz, presidente da Câmara Municipal de Fortaleza, conselheiro geral da província, secretário e conselheiro do Governo, deputado provincial, dentre outros. Cf. STUDART, op. Cit., p. 384.

${ }^{13}$ STUDART, Barão de. Conselho Geral da Província do Ceará. Revista do Instituto do Ceará, t. XXXVI, 1922 , p. 474.

${ }^{14}$ MOREL, Op. Cit.

${ }^{15}$ Ver os ofícios $n^{\circ} 23$ de 12 de julho e $\mathrm{n}^{\mathrm{o}} 31$ de 18 de agosto de 1831 em APEC. Registro dos ofícios do Presidente de Província ao Secretário dos Negócios do Império. 1829 - 1831, cx. 5, livro 14 (antigo 16-B). Fundo Governo da Província. Digitalizado no DVD Governo da Província 2, pasta 04.05.2010.

${ }^{16}$ Ofício $n^{\circ} 23$ de 12 de julho de 1831 em APEC, Registro dos ofícios..., fl. 71 (grifo nosso).

${ }^{17}$ Ofício no 31 de 18 de agosto de 1831 em APEC, Registro de ofícios..., fl. 78 (grifo nosso).

${ }^{18}$ Ofício de 13 de maio de 1831, em APEC. Ofícios expedidos a diversas autoridades. 1829 - 1833, cx. 5, livro 15 (antigo 19-B). Fundo Governo da Província. Digitalizado no DVD Governo da Província 2, pasta 04.05.2010, fl. 62 (grifo nosso)

${ }^{19}$ Movimento liberal ocorrido em Portugal, desencadeado pela Revolução do Porto em agosto de 1820, fruto da insatisfação generalizada que se estabeleceu com a vinda da Família Real para o Brasil em 1808 e que tinha como base reformas políticas, econômicas e sociais através da convocação das Cortes de Lisboa e da elaboração de uma Constituição para o Reino Português. Cf. NEVES, Op. Cit.

${ }^{20}$ Ver o $2^{\circ}$ capítulo de SOUZA, Iara Lis Franco Schiavinatto Carvalho. A pátria coroada: o Brasil como corpo político autônomo 1780 - 1831. Tese (Doutorado em História) - Instituto de Filosofia e Ciências Humanas, Universidade Estadual de Campinas, Campinas, 1997.

${ }^{21}$ NEVES, Op. Cit., p. 171.

${ }^{22}$ Foi uma das figuras mais destacadas do campo político da província e do Império. Por conta da trajetória e da influência que construiu, foi um dos grandes articuladores na constituição do partido liberal moderado no Ceará e nas relações que se estabeleciam com a Corte. Sua trajetória política se inicia já em 1817, quando ainda estudante no Seminário de Olinda foi encarregado de levar a Revolução Pernambucana para a província cearense. Foi eleito deputado para as Cortes de Lisboa em 1821, participou da Confederação do Equador em 1824 (mesmo renegando tal participação em um pedido de perdão ao imperador D. Pedro I), eleito deputado geral em 1830, senador dois anos depois e presidente da província do Ceará em 1834. Cf. STUDART, 2012, p. 155. O documento em que pede o perdão do Imperador por seu envolvimento no movimento de 1824 está como anexo em THÉBERGE, Dr. Pedro. Esboço histórico sobre a província do Ceará. t. III. Edição fac-sim. Fortaleza: Fundação Waldemar Alcântara, 2001b (1895).

23 ANNAES do Parlamento Brasileiro. Camara dos Srs. Deputados: Primeiro Anno da Segunda Legislatura. Sessão de 1830, colligidos por Antonio Pereira Pinto em virtude da resolução da mesma Câmara. t. I. Rio de Janeiro: Typographia de H. J. Pinto, 1878, p. 50. Disponível em: <http://imagem.camara.gov.br/pesquisa_diario_basica.asp>. Acesso em: 20 nov. 2013.

${ }^{24}$ BASILE, Op. Cit., p. 42.

${ }^{25}$ MOREL, Op. Cit., p. 119.

${ }^{26}$ BASILE, Op. Cit., p. 55.

${ }^{27}$ Esta importante família de Aracati detivera grande força política durante o Império, estando do lado legalista na repressão às rebeliões de 1817 e 1824 e ligando-se aos moderados durante as Regências. A tipografia onde era impresso tal jornal era propriedade de Joaquim José Barbosa, que nasceu em Aracati, mas montou residência em Sobral, onde se instalou como negociante e se casou com a filha do Capitão-mor agregado de Sobral e Fortaleza Antonio José da Silva Castro, assim consolidando a aliança familiar com os Castro. Foi bastante influente na política, ocupando diversos cargos do Estado, sejam eletivos ou por nomeação, incluindo-se deputado geral e provincial. Cf. STUDART, 2012.

${ }^{28}$ Aliado da família Castro e nascido em Icó, este redator era advogado e ocupou diversos cargos da burocracia imperial, sendo também vereador de Fortaleza, conselheiro da província, conselheiro de governo e deputado provincial na legislatura de 1838 - 1839. O apelido Doutor Rapadura, segundo Hugo Guimarães, era decorrente do apresso que tinha pelo doce, não se furtando a comê-lo quando bem lhe conviesse. Ver GUIMARÃES, Hugo Victor. Deputados provinciais e estaduais do Ceará: Assembleia Legislativa 1835 - 1947. Fortaleza: Ed. Jurídica Ltda., 1951. 
${ }^{29}$ (Artigo sem título). Semanário Constitucional, n. 34, Ceará, 23 abr. 1831, p. 129 - 131.

${ }^{30}$ BASILE, Op. Cit.

${ }^{31}$ SILVA, Wlamir. Liberais e povo: a construção da hegemonia liberal-moderada na província de Minas Gerais (1830 - 1834). São Paulo: Aderaldo \& Rothschild; Belo Horizonte: FAPEMIG, 2009, p. 197.

${ }^{32}$ Por elite política entendemos os agentes sociais que dominavam o campo político (uma minoria da população), controlando os espaços de poder e visando a direção política provincial, tendo acesso privilegiado aos espaços de nível nacional. Alternavam-se na ocupação dos cargos institucionais do Estado na província e possuíam influência social destacada para disputarem o controle das eleições. Seu poder político, para o contexto em que se insere esta pesquisa, geralmente advinha do poder econômico individual ou familiar que respaldava a sua ascensão na sociedade. Porém, não existia unidade nesta elite, já que se situavam em um campo de disputa, o campo político. Sobre este conceito, ver BOURDIEU, Pierre. O Poder simbólico. 14. ed. Rio de Janeiro: Bertrand Brasil, 2010. A elite econômica englobava sujeitos que através, sobretudo, da grande propriedade rural e/ou da atuação comercial, acumulavam influência social e poder diante da população de um modo geral.

${ }^{33}$ Ver COSTA, Vivian Chieregati. Codificação e formação do Estado-nacional brasileiro: o Código Criminal de 1830 e a positivação das leis no pós-Independência. Dissertação (Mestrado em Culturas e Identidades Brasileiras) - Instituto de Estudos Brasileiros, Universidade de São Paulo, São Paulo, 2013.

${ }^{34}$ Ver COSTA, Op. Cit.

${ }^{35}$ Personalidade ativa na política local e dos principais membros do partido moderado no Ceará.

${ }^{36}$ SR. REDATOR. Cearense Jacauna, n. 75, Ceará, 17 out. 1832, p. ilegível [3ª pág. da publicação]. (acervo Fundação Biblioteca Nacional).

${ }^{37}$ Id. Ib., p. ilegível [ $4^{\mathrm{a}}$ pág. da publicação]) (acervo Fundação Biblioteca Nacional).

${ }^{38}$ BASILE, Op. Cit., p. 44.

${ }^{39}$ No Cearense Jacauna de 24 de outubro de 1832, utilizou-se este termo: "Hoje no tempo da Liberdade Constitucional [...]" (p. 268).

40 Sobre este tema, cf. HOLANDA, Sérgio Buarque de. A herança colonial - sua desagregação. In:

(org.). História Geral da Civilização Brasileira. O Brasil Monárquico: o processo de emancipação. $2 . \overline{\text { ed. t. II. }^{\circ}}$ volume. São Paulo: Difusão Européia do Livro, 1965.

41 CARVALHO, José Murilo. Cidadania no Brasil: o longo caminho. 11. ed. Rio de Janeiro: Civilização Brasileira, 2008, p. 9 - 10.

${ }^{42}$ FERES JÚNIOR, João (org.). Léxico da história dos conceitos políticos no Brasil. Belo Horizonte: Editora UFMG, 2009, p. 58 .

${ }^{43}$ Mesmo com pré-requisitos que excluíam grande parte da população da participação política, José Murilo de Carvalho considera a Constituição de 1824 uma das mais liberais do período, pois dentre outras justificativas, analfabetos e libertos não eram impedidos de votar e a porcentagem de votantes era maior do que em alguns países europeus, já que não seria tão difícil acumular em um ano a renda mínima estipulada. Cf. CARVALHO, Op. Cit.

${ }^{44}$ Ver art. 92 de BRAZIL. Constituição Política do Império do Brasil. Coleção de Leis do Império do Brasil de

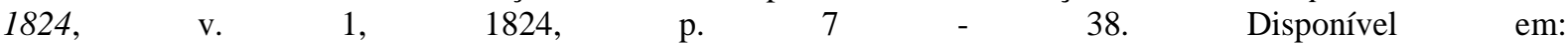
<http://www.camara.gov.br/Internet/InfDoc/conteudo/colecoes/Legislacao/Const_1824.pdf>. Acesso em: 18 nov. 2013.

${ }^{45}$ RODRIGUES, Antonio E. M.; FALCON, Francisco J. C.; NEVES, Margarida de S. A Guarda Nacional no Rio de Janeiro (1831-1918). Rio de Janeiro: PUC-RJ, 1981.

${ }^{46}$ MATTOS, Ilmar Rohloff. O tempo saquarema. 5. ed. São Paulo: Hucitec, 2004, p. 128.

${ }^{47}$ RÉMOND, René. Introdução à história do nosso tempo: do Antigo Regime aos nossos dias. 4. ed. Lisboa: Gradiva, 2011, p. 118.

${ }^{48}$ Sobre a Guarda Nacional, ver também CASTRO, Jeanne Berrance de. A Milícia Cidadã: a Guarda Nacional de 1831 a 1850. 2. ed. São Paulo: Ed. Nacional, 1979; URICOECHEA, Fernando. O Minotauro Imperial: a burocratização do Estado patrimonial brasileiro no século XIX. Rio de Janeiro - São Paulo: DIFEL, 1978; ALENCAR, Gustavo Magno Barbosa. Guarda Nacional, Estado, sociedade: permanências e intervenções na Milícia Cívica cearense (1836 - 1841). Monografia (Licenciatura Plena em História) - Centro de Humanidades, Universidade Estadual do Ceará, Fortaleza, 2011.

${ }^{49}$ Ver NEVES, Op. Cit. e FERES JÚNIOR, Op. Cit.

${ }^{50}$ Correspondencia official sobre as Eleições do Aracati. Continuação do n. antecedente. Correio da Assemblea Provincial, n. 3, Ceará, 21 jan. 1837, p. 2 (grifos nossos).

${ }^{51}$ FERES JÚNIOR, Op. Cit., p. 219.

${ }^{52}$ MATTOS, Op. Cit., p. 125. 


\footnotetext{
${ }^{53}$ BRAZIL. Lei de 16 de dezembro de 1830: Manda executar o Codigo Criminal. Coleção de Leis do Império do Brasil, v. 1, pt. I, 1830, p. 142. Disponível em: <http://www2.camara.leg.br/legin/fed/lei_sn/1824-1899/lei38059-16-dezembro-1830-565840-publicacaooriginal-89575-pl.html>. Acesso em: 18 dez. 2013.

${ }^{54}$ Correio da Assemblea Provincial, n. 2, Ceará, 14 jan. 1837, p. 3 (grifos nossos).

${ }^{55}$ Ofício no 21 de 25 de junho de 1831. APEC, 1829-1831, fl. $69-69 \mathrm{v}$.

${ }^{56}$ Idem, fl. 69v. Grifo nosso.

${ }^{57}$ STUDART, 1922, p. 475 (grifo nosso).

${ }^{58}$ MATTOS, Op. Cit., p. 135.

${ }^{59}$ As diferenças na sociedade imperial eram estabelecidas a partir de alguns elementos: a liberdade, o "atributo racial, o grau de instrução, a propriedade de escravos e sobretudo os vínculos pessoais que cada qual conseguia estabelecer. E dessa forma, a sociedade imprimia-se nos indivíduos que a compunham, distinguindo-os, hierarquizando-os e forçando-os a manter vínculos pessoais”. MATTOS, Op. Cit., p. 138.

${ }^{60}$ RIBEIRO, Gladys Sabina. O desejo da liberdade e a participação de homens livres pobres e "de cor" na Independência do Brasil. Cadernos Cedes, v. 22, n. 58, p. 21-45, dezembro/2002. Disponível em: <http://www.cedes.unicamp.br>. Acesso em: 8 jan. 2014.

${ }^{61}$ SILVA, Op. Cit.

${ }^{62}$ BOURDIEU, Pierre. O Poder simbólico. 14. ed. Rio de Janeiro: Bertrand Brasil, 2010, p. 142.

${ }^{63}$ Idem, p. 165.

${ }^{64}$ Uma disputa que carrega sua complexidade e que pelas dimensões deste artigo acabou não sendo possível sua abordagem aprofundada. Esta foi melhor desenvolvida ao longo do estudo: ALENCAR, Gustavo Magno Barbosa. Pelas tramas da política: a constituição do partido liberal moderado na província do Ceará (18301837). Dissertação (Mestrado) - Universidade Federal do Ceará, Programa de Pós-graduação em História, Fortaleza (CE), 2014.
}

\section{Referências bibliográficas}

ALENCAR, Gustavo Magno Barbosa. Pelas tramas da política: a constituição do partido liberal moderado na província do Ceará (1830-1837). Dissertação (Mestrado) - Universidade Federal do Ceará, Programa de Pós-graduação em História, Fortaleza (CE), 2014.

BASILE, Marcello Otávio Neri de Campos. O Império em construção: projetos de Brasil e ação política na Corte Regencial. Tese (Doutorado em História Social) - Instituto de Filosofia e Ciências Sociais, Universidade Federal do Rio de Janeiro, Rio de Janeiro, 2004.

BOURDIEU, Pierre. O Poder simbólico. 14. ed. Rio de Janeiro: Bertrand Brasil, 2010

CARVALHO, José Murilo. Cidadania no Brasil: o longo caminho. 11. ed. Rio de Janeiro: Civilização Brasileira, 2008, p. 9 - 10.

COSTA, Vivian Chieregati. Codificação e formação do Estado-nacional brasileiro: o Código Criminal de 1830 e a positivação das leis no pós-Independência. Dissertação (Mestrado em Culturas e Identidades Brasileiras) - Instituto de Estudos Brasileiros, Universidade de São Paulo, São Paulo, 2013.

FELIX, Keile Socorro Leite. "Espíritos inflamados": a construção do Estado nacional brasileiro e os projetos políticos no Ceará (1817 - 1840). Dissertação (Mestrado em História Social) - Centro de Humanidades, Universidade Federal do Ceará, Fortaleza, 2010.

FERES JÚNIOR, João (org.). Léxico da história dos conceitos políticos no Brasil. Belo Horizonte: Editora UFMG, 2009, p. 58.

GUIMARÃES, Hugo Victor. Deputados provinciais e estaduais do Ceará: Assembleia Legislativa 1835 - 1947. Fortaleza: Ed. Jurídica Ltda., 1951.

HOLANDA, Sérgio Buarque de. A herança colonial - sua desagregação. In:

(org.). História Geral da Civilização Brasileira. O Brasil Monárquico: o processo de emancipação. 2. ed. t. II. $1^{\circ}$ volume. São Paulo: Difusão Européia do Livro, 1965. 
NEVES, Lúcia Maria Bastos Pereira das. Corcundas e constitucionais: a cultura política da Independência (1820-1822). Rio de Janeiro: Editora Revan/ FAPERJ, 2003.

MATTOS, Ilmar Rohloff. O tempo saquarema. 5. ed. São Paulo: Hucitec, 2004, p. 128.

MOREL, Marco. As transformações dos espaços públicos: imprensa, atores políticos e sociabilidades na Cidade Imperial (1820 - 1840). $2^{\mathrm{a}}$ ed. São Paulo: Editora Hucitec, 2010.

MOTTA, Rodrigo Patto Sá. Desafios e possibilidades na apropriação de cultura política pela historiografia. In:

Argvmentvm Editora, 2009 Culturas políticas na História: novos estudos. Belo Horizonte:

RÉMOND, René. Introdução à história do nosso tempo: do Antigo Regime aos nossos dias. 4. ed. Lisboa: Gradiva, 2011, p. 118.

RIBEIRO, Gladys Sabina. O desejo da liberdade e a participação de homens livres pobres e "de cor" na Independência do Brasil. Cadernos Cedes, v. 22, n. 58, p. 21-45, dezembro/2002. Disponível em: <http://www.cedes.unicamp.br>. Acesso em: 8 jan. 2014.

RODRIGUES, Antonio E. M.; FALCON, Francisco J. C.; NEVES, Margarida de S. A Guarda Nacional no Rio de Janeiro (1831-1918). Rio de Janeiro: PUC-RJ, 1981.

SILVA, Wlamir. Liberais e povo: a construção da hegemonia liberal-moderada na província de Minas Gerais (1830 - 1834). São Paulo: Aderaldo \& Rothschild; Belo Horizonte: FAPEMIG, 2009, p. 197.

SOUZA, Iara Lis Franco Schiavinatto Carvalho. A pátria coroada: o Brasil como corpo político autônomo 1780 - 1831. Tese (Doutorado em História) - Instituto de Filosofia e Ciências Humanas, Universidade Estadual de Campinas, Campinas, 1997.

STUDART, Barão de. Conselho Geral da Província do Ceará. Revista do Instituto do Ceará, t. XXXVI, 1922.

STUDART, Guilherme. Diccionário bio-bibliográphico cearense II. Edição fac-simile. Fortaleza: Iris; Secult, 2012 (1913), p. 105.

THÉBERGE, Dr. Pedro. Esboço histórico sobre a província do Ceará. t. III. Edição fac-sim. Fortaleza: Fundação Waldemar Alcântara, 2001b (1895).

THOMPSON, E. P. A miséria da teoria ou um planetário de erros: uma crítica ao pensamento de Althusser. Tradução de Waltensir Dutra. Rio de Janeiro: Zahar Editores, 1981. 